\title{
Analysis of the Coping Strategies of Primary Health Care Professionals: Cross-Sectional Study in a Large Brazilian
}

\section{Municipality}

Luciano Garcia Lourenção',2,*, Bruno Martinez Rigino², Natalia Sperli Geraldes Marin dos Santos Sasaki², Maria Jaqueline Coelho Pinto², Francisco Rosemiro Guimarães Ximenes Neto³, Flávio Adriano Borges Melo4, Maria de Lourdes Sperli Geraldes Santos ${ }^{2}$, José Gustavo Monteiro Penha ${ }^{1}$, Daniela Menezes Galvão ${ }^{1}$, Betânia Maria Pereira dos Santos, ${ }^{5,6}$, Isabel Cristina Kowal Olm Cunha7, Jacqueline Flores de Oliveira ${ }^{1}$, Max dos Santos Afonso', Carlos Leonardo Figueiredo Cunhas, Francielle Garcia da Silva1, Neyson Pinheiro Freire, ${ }^{6,7}$, Vagner Ferreira do Nascimento ${ }^{9}$, Sidiane Teixeira Rodrigues ${ }^{1}$, Taisa Moitinho de Carvalho ${ }^{2}$, Messias Lemos $^{10}$, Juliana Lima da Cunha ${ }^{1}$, Neide Aparecida Micelli Domingos ${ }^{2}$

\footnotetext{
Nursing School, Federal University of Rio Grande, Rio Grande, Rio Grande do Sul, Brazil

2 School of Medicine of São José do Rio Preto. São José do Rio Preto, São Paulo, Brazil

3 Health Sciences Center, Vale do Acaraú State University. Sobral, Ceará, Brazil

4 Nursing Department, Federal University of São Carlos. São Carlos, São Paulo, Brazil

5 Technical School of Health, Federal University of Paraíba. João Pessoa, Paraíba, Brazil

6 Federal Council of Nursing. Brasília, Federal District, Brazil

Paulista School of Nursing, Federal University of Sao Paulo. São Paulo, São Paulo, Brazil

8 Nursing School, Federal University of Pará. Belém, Pará, Brazil

9 Mato Grosso State University. Tangará da Serra, Mato Grosso, Brazil

10 Nursing Department, Federal University of Santa Catarina. Florianópolis, Santa Catarina, Brazil

* Correspondence: lucinaolourencao.enf@gmail.com
}

\begin{abstract}
The aim was to analyze the coping strategies used by primary health care (PHC) professionals. A cross-sectional, descriptive-analytical study was conducted with professionals working in primary health care units in São José do Rio Preto, a large city in the interior of São Paulo, Brazil. For data collection we used an instrument developed by the researchers, containing sociodemographic and professional variables, as well as the Problem Coping Modes Scale (EMEP). We evaluated 333 PHC professionals. A difference was observed between the scores of the four coping strategies $(p<0.001)$, with the highest score for the problem-focused strategy (3.8) and the lowest score for the emotion-focused strategy (2.4). Physicians had the lowest scores in coping strategies focused on religious practices/fantastical thinking $(\mathrm{p}<0.001)$ and pursuit of social support $(\mathrm{p}=0.045)$, while community health agents had the highest scores in these coping strategies). Professionals working in PHC have different coping strategies for the problems and stressful situations experienced in the work environment. These strategies can involve more positive attitudes focused on confrontation and problem solving, to emotional responses that involve attitudes of avoidance and denial that involve attitudes of avoidance and denial of the problem.
\end{abstract}

Keywords: primary health care; family health strategy; health personnel; adaptation, psychological. 


\section{Introduction}

In Brazil, Primary health care (PHC) or basic health care (BHC) is the first level of health care in the Unified Health System (SUS) and represents the "entrance door" to the public health system. The Family Health Strategy (FHS) is the priority model of health care in PHC [1].

Professionals in FHS teams work with client assignment, home visits, integrality of practice, and health promotion. They are multiprofessional teams, composed of a general physician (preferably a specialist in Family and Community Medicine), a nurse (preferably a specialist in Family Health), a nursing assistant and/or a nursing technician, and community health workers (CHWs) [1,2].

The organization and work process of PHC professionals can induce stress, which is understood as a psychological, physiological, and behavioral response of the worker to environmental, physical, and social situations that generate pressures and exhaustion [3]. The overload and the precariousness of the work conditions, the fragility of the employment bonds, the lack of training and perspectives of professional growth, the pressure for the fulfillment of goals and the lack of professional autonomy are identified as the main causes of psychological suffering among PHC professionals [4-10].

To adapt to these stressful events, the workers expends a great amount of adaptive energy and, for this reason, in high levels or chronic situations, stress can cause physical and psychological illness, leading to difficulties facing problems and situations that feel threatening and/or wearying, and compromising the quality of life of workers [5,11-13].

When under stress, professionals seek coping strategies, which consist of cognitive, emotional, and behavioral reactions intentionally adopted to help them adapt to stressful situations and decrease susceptibility and negative impacts [14,15].

These coping strategies can be problem-focused (focused on ways to manage or solve the problem, re-evaluation, and positive meaning of the stressor), emotion-focused (involving avoidance behaviors, denial, emotions expressing anger and tension, attribution of blame, withdrawal from the problem, and ameliorative actions in the face of the stressor), based on religious or spiritually-related practices and fantastical thinking, or based on the pursuit of social support (pursuit of emotional or instrumental social support and the search for information) [16]. These coping strategies define different ways in which PHC professionals might deal with daily stress situations, avoid damage to health, produce motivation, and improve job satisfaction [17].

Moreover, coping strategies have an important protective role against the development of Burnout Syndrome (a state in which a person feels overwhelmed, immobilized, and feels reduced motivation) and directly influence the quality of life of professionals [12,18]. Coping strategies are used to reduce or eliminate suffering caused by stressors, and utilize internal and external resources such as social skills, beliefs, health condition, and availability of material resources [14,19-22].

Studies with health professionals in hospital services indicate that the most commonly adopted coping strategies are problem solving and social support, which consist of behavioral strategies aimed at solving the problem and cognitive strategies aimed at perceiving the stressor as a positive experience, in addition to seeking out information and socioemotional support [23,24]. Similarly, in studies with psychologists from a Psychosocial Care Center (CAPS) and with community health workers, the authors showed that problem solving strategies are more frequently used and more positively perceived by professionals $[25,26]$.

In this context, understanding the coping strategies adopted by PHC professionals can contribute to the implementation of policies that promote positive coping mechanisms and improve the quality of life and productivity of this population, and by realizing this, we can improve the mental health of PHC workers.

Given the above, this study aimed to analyze the coping strategies used by workers in PHC. 


\section{Materials and Methods}

\subsection{Type of Study}

This cross-sectional, descriptive-analytical study was conducted in 2017 with professionals working in the Primary Health Care units of a large municipality in the northwestern region of the state of São Paulo, Brazil. This municipality is the headquarters of the Regional Health Department (DRS) XV, which serves a total of 102 municipalities.

This large municipality had, at the time of the study, an estimated population of 451,354 inhabitants [27] and was administratively organized into five Health Districts. Primary Care comprised 27 health units, which had 58 teams of the FHS [28].

\subsection{Sample and Participants}

The population of this study consisted of 351 workers (physicians, nurses, nursing assistants/technicians, and community health workers) from 27 PHC units in the municipality. The sample was defined by convenience and included 333 professionals who responded to the data collection instruments.

\subsection{Procedures, Measurements, Variables and Outcome}

For data collection, two self-administered instruments were used: Firstly, a questionnaire developed by the researchers, containing sociodemographic variables (gender, age, marital status, education, family income) and professional variables (professional category, type of contract, weekly workload, time working in PHC, satisfaction with the profession). Secondly, the Problem Coping Modes Scale (EMEP), which encompasses thoughts and actions that individuals use to deal with the internal or external demands of a specific stressful event and consists of 45 items that address four factors, namely, problem-focused coping strategies, emotion-focused coping strategies, pursuit of religious practices/fantastical thinking, and pursuit of social support [16].

The EMEP items were answered on a Likert-type scale with five possible responses: $1=\mathrm{I}$ never do this; 2 = I hardly ever do this; 3 = I do this sometimes; 4 = I do this a lot; 5 = I always do this. The characterization of coping occurs from the comparison between the mean obtained in each factor, as follows: factor 1 [Coping focused on the problem], which consisted of items 1, 3, 10, 14, 15, 16, 17, 19, 24, 28, 30, 32, 33, 36, 39, 40, 42, and 45; factor 2 [Coping focused on emotion], which consisted of items 2, 5, 11, 12, 13, 18, 20, 22, 23, 25, $29,34,35,37$, and 38; factor 3 [Coping based on religious practices and fantastical thinking], which consisted of items 6, 8, 21, 26, 27, 41, and 44; factor 4 [Coping based on social support], which consisted of items $4,7,9,31$, and 43 [16].

\subsection{Statistical Analysis}

The data were analyzed using the Statistical Package for Social Sciences (SPSS), version 20.0. To evaluate the coping modes, the mean scores of the four strategies (problem-focused, emotion-focused, religiosity/spirituality, social support), the standard deviation, the $95 \%$ confidence interval $(95 \% \mathrm{CI})$, and Cronbach's alpha coefficient $(\alpha)$ were obtained. The internal consistency of the EMEP scale factors, measured by Cronbach's alpha coefficient, was 0.879 for the problem-focused strategy, 0.804 for the emotion-focused strategy, 0.587 for the strategy based on religious practices/fantastical thinking, and 0.682 for the strategy based on social support.

The comparison of coping strategies with the socio-demographic and professional variables of PHC workers was performed with the t-test for two means or analysis of variance (ANOVA) and for three or more means, considering a significance level of $5 \%$ $(\mathrm{p} \leq 0.05)$. 


\subsection{Ethical Considerations}

Ethical approval regarding this study was obtained from the institutional ethics committee (decision: 1,776,737 - October 16, 2016; CAAE: 59604116.0.0000.5415). All the participants in this study were only included after informed consent had been obtained from them. All procedures performed in this study were in accordance with the ethical standards of the institutional research committee and with the comparable ethical standards outlined in the Declaration of Helsinki.

\section{Results}

A total of 333 PHC workers participated in this study, of which 32 (9.6\%) were physicians, $20(6.0 \%)$ were nurses, $77(23.1 \%)$ were nursing assistants/technicians, and 71 $(21.3 \%)$ were community health agents. Participants were predominantly female $(81.1 \%)$, 60 years old or above (44.7\%), with higher education $(55.3 \%)$, married or in a stable union (63.1\%), permanent employees $(74.5 \%)$, with 40 working hours per week $(91.0 \%)$, with family income of two to 10 minimum wages (56.8\%), up to two years working in PHC $(37.8 \%)$ and satisfied with the profession $(77.8 \%)$ (Table 1$)$.

Table 1 - Sociodemographic and professional characteristics of Primary Health Care (PHC) workers in São José do Rio Preto, São Paulo, Brazil.

\begin{tabular}{|c|c|c|}
\hline Variables & $\mathbf{n}$ & $\%$ \\
\hline \multicolumn{3}{|l|}{ Professional Category } \\
\hline Physician & 32 & 9.6 \\
\hline Nurse & 20 & 6.0 \\
\hline Nursing Auxiliary/Technician & 77 & 23.1 \\
\hline Community Health Agent & 71 & 21.3 \\
\hline No answer & 133 & 39.9 \\
\hline \multicolumn{3}{|l|}{ Sex } \\
\hline Male & 60 & 18.0 \\
\hline Female & 270 & 81.1 \\
\hline No answer & 3 & 0.9 \\
\hline \multicolumn{3}{|l|}{ Age Group (years) } \\
\hline 18 to 28 & 1 & 0.3 \\
\hline 29 to 39 & 32 & 9.6 \\
\hline 40 to 59 & 138 & 41.4 \\
\hline 60 or more & 149 & 44.7 \\
\hline No answer & 13 & 3.9 \\
\hline \multicolumn{3}{|l|}{ Education } \\
\hline High School & 149 & 44.7 \\
\hline Higher Education / Graduate & 184 & 55.3 \\
\hline \multicolumn{3}{|l|}{ Civil Status } \\
\hline Married / Stable Union & 210 & 63.1 \\
\hline Single & 86 & 25.8 \\
\hline Separated & 28 & 8.4 \\
\hline Widowed & 9 & 2.7 \\
\hline \multicolumn{3}{|l|}{ Contract Type } \\
\hline Government employee & 248 & 74.5 \\
\hline Hired & 80 & 24.1 \\
\hline
\end{tabular}




\begin{tabular}{|c|c|c|}
\hline No answer & 3 & 0.9 \\
\hline \multicolumn{3}{|l|}{ Weekly Work Hours } \\
\hline 20 hours & 20 & 6.0 \\
\hline 30 hours & 8 & 2.4 \\
\hline 40 hours & 303 & 91.0 \\
\hline No answer & 2 & 0.6 \\
\hline \multicolumn{3}{|c|}{ Family Income (number of minimum } \\
\hline \multicolumn{3}{|l|}{ wages*) } \\
\hline Up to one & 23 & 6.9 \\
\hline Two to five & 189 & 56.8 \\
\hline Six to 10 & 66 & 19.8 \\
\hline More than 10 & 47 & 14.1 \\
\hline No answer & 8 & 2.4 \\
\hline \multicolumn{3}{|c|}{ Length of time working in PHC } \\
\hline Up to two years & 126 & 37.8 \\
\hline$>$ two and $\leq$ five years & 56 & 16.8 \\
\hline$>$ five and $\leq 10$ years & 64 & 19.2 \\
\hline Over 10 years & 71 & 21.3 \\
\hline No answer & 16 & 4.8 \\
\hline \multicolumn{3}{|l|}{ Satisfied with Profession } \\
\hline Yes & 259 & 77.8 \\
\hline No & 70 & 21.0 \\
\hline No answer & 4 & 1.2 \\
\hline
\end{tabular}

As shown in Table 2, there was a statistically significant difference between the scores of the four coping strategies $(\mathrm{p}<0.001)$. The highest score obtained was in the factor "problem-focused", which corresponds to behavioral strategies aimed at managing or solving the problem and cognitive strategies aimed at re-evaluation and positive meaning-making regarding the stressor. The lowest score corresponds to the "emotion-focused" factor, that is, the cognitive and behavioral strategies that involve avoidance, denial, expressing emotions of anger and tension, attribution of blame, withdrawal from the problem, and ameliorative actions in the face of the stressor.

Table 2. Mean scores of the coping strategies of Primary Health Care workers in São José do Rio Preto, São Paulo, Brazil.

\begin{tabular}{lcccc}
\hline \multicolumn{1}{c}{ Coping Strategy } & $\begin{array}{c}\text { Mean } \\
\text { Score }\end{array}$ & $\begin{array}{c}\text { Standard } \\
\text { Deviation }\end{array}$ & $\mathbf{9 5 \% \mathbf { C I } ^ { * }}$ & $\begin{array}{c}\text { p-value } \\
\text { (t-test })\end{array}$ \\
\hline Problem-focused & 3.8 & 0.66 & $3.7-3.9$ & \\
$\begin{array}{l}\text { Emotion-focused } \\
\text { Religious Practices }\end{array}$ & \multicolumn{1}{c}{$/ .4$} & 0.62 & $2.4-2.5$ & \\
$\begin{array}{l}\text { Fantastical Thinking } \\
\text { Pursuit of Social Support }\end{array}$ & 3.2 & 0.78 & $3.1-3.3$ & $<0.001$ \\
\hline
\end{tabular}

* 95\% Confidence Interval. 
Analysis of the coping strategies according to the sociodemographic and professional variables of the PHC workers showed that there was no statistically significant difference between the scores of coping strategies and the type of contract, weekly work hours, and marital status ( $\mathrm{p}>0.05)$.

As observed in Table 3, physicians presented the lowest scores in the coping strategies focused on religious practices/fantastical thinking $(\mathrm{p}<0.001)$ and pursuit of social support ( $\mathrm{p}=0.045$ ), while community health agents scored the highest in these strategies. Similarly, females showed higher scores than males for the coping strategies focused on religious practices/fantastical thinking $(\mathrm{p}=0.001)$ and pursuit of social support $(\mathrm{p}=0.005)$.

Younger workers (18 to 28 years old) had significantly higher scores than workers aged 60 years and older for the emotion-focused coping strategy $(p=0.014)$. Workers whose family income was up to one minimum wage presented higher scores for the coping strategy focused on religious practices/fantastical thinking than those with family income higher than 10 minimum wages $(\mathrm{p}=0.001)$.

Workers with more than 10 years of professional PHC experience presented the lowest scores for the coping strategies focused on emotion $(\mathrm{p}=0.008)$ and on religious practice/fantastical thinking $(\mathrm{p}<0.001)$. Further, workers who reported being dissatisfied with their profession had higher scores for the coping strategies focused on emotion $(p=0.011)$ and religious practices/fantastical thinking $(p<0.010)$ than those who reported being satisfied with their profession (Table 3).

Table 3. Mean scores of the coping strategies of PHC workers, according to sociodemographic and professional variables. São José do Rio Preto, São Paulo, Brazil.

\begin{tabular}{|c|c|c|c|c|}
\hline \multirow[t]{2}{*}{ Coping Strategy } & Problem-focused & Emotion-focused & $\begin{array}{c}\text { Religious } \\
\text { Practices / } \\
\text { Fantastical } \\
\text { Thinking }\end{array}$ & $\begin{array}{c}\text { Pursuit of } \\
\text { Social } \\
\text { Support }\end{array}$ \\
\hline & $\operatorname{Mean}\left(S D^{*}\right)$ & $\operatorname{Mean}\left(S D^{*}\right)$ & $\operatorname{Mean}\left(S D^{*}\right)$ & Mean $\left(S D^{*}\right)$ \\
\hline \multicolumn{5}{|l|}{ Professional Category } \\
\hline Physician & $3.9(1.5)$ & $3.6(1.8)$ & $2.3(1.9)$ & $3.0(1.5)$ \\
\hline Nurse & $3.5(1.4)$ & $3.6(1.3)$ & $3.2(1.4)$ & $3.7(1.4)$ \\
\hline $\begin{array}{l}\text { Nurse } \\
\text { Auxiliary/Technician }\end{array}$ & $3.7(1.3)$ & $4.0(1.2)$ & $3.7(1.2)$ & $3.7(1.3)$ \\
\hline $\begin{array}{l}\text { Community Health } \\
\text { Agent }\end{array}$ & $3.8(1.3)$ & $4.3(1.4)$ & $4.2(1.2)$ & $3.8(1.3)$ \\
\hline$p$-value $e^{* *}$ & 0.136 & 0.091 & $<0.001$ & 0.045 \\
\hline \multicolumn{5}{|l|}{ Sex } \\
\hline Male & $3.9(0.7)$ & $2.5(0.7)$ & $2.9(0.8)$ & $2.8(1.0)$ \\
\hline Female & $3.8(0.7)$ & $2.4(0.6)$ & $3.3(0.8)$ & $3.2(0.9)$ \\
\hline$p$-value $e^{* * *}$ & 0.495 & 0.872 & 0.001 & 0.005 \\
\hline \multicolumn{5}{|l|}{ Age Group (years) } \\
\hline 18 to 28 & $3.4(0.8)$ & $3.8(0.6)$ & $3.8(0.5)$ & $3.8(0.5)$ \\
\hline 29 to 39 & $3.3(0.5)$ & $3.5(0.7)$ & $3.5(0.7)$ & $3.5(0.7)$ \\
\hline 40 to 59 & $3.4(0.8)$ & $3.4(0.7)$ & $3.4(0.7)$ & $3.4(0.7)$ \\
\hline 60 or more & $3.4(0.8)$ & $2.8(0.5)$ & $3.3(0.7)$ & $3.4(0.8)$ \\
\hline$p$-value $e^{* * *}$ & 0.926 & 0.014 & 0.235 & 0.271 \\
\hline \multicolumn{5}{|l|}{ Education } \\
\hline High School & $1.5(0.5)$ & $1.6(0.5)$ & $1.8(0.4)$ & $1.9(0.4)$ \\
\hline
\end{tabular}




\begin{tabular}{|c|c|c|c|c|}
\hline \multicolumn{5}{|l|}{$\begin{array}{l}\text { Higher Education / } \\
\text { Graduate }\end{array}$} \\
\hline$p$-value $e^{* * *}$ & 0.860 & 0.111 & $<0.001$ & 0.168 \\
\hline \multicolumn{5}{|c|}{ amily Income (number of minimum wages§) } \\
\hline Up to one & $2.2(0.4)$ & $2.6(1.2)$ & $3.5(1.0)$ & $2.9(1.0)$ \\
\hline Two to five & $2.5(0.8)$ & $2.5(0.8)$ & $2.6(0.8)$ & $2.5(0.8)$ \\
\hline Six to 10 & $2.4(0.8)$ & $2.4(0.8)$ & $2.5(0.8)$ & $2.4(0.8)$ \\
\hline More than 10 & $2.5(0.8)$ & $2.3(0.5)$ & $2.3(0.8)$ & $2.4(0.8)$ \\
\hline$p$-value $e^{* *}$ & 0.701 & 0.259 & 0.001 & 0.290 \\
\hline
\end{tabular}

Length of time working in PHC

\begin{tabular}{|c|c|c|c|c|}
\hline Up to two years & $3.3(0.6)$ & $2.4(1.3)$ & $2.5(1.0)$ & $3.3(1.4)$ \\
\hline$>$ two and $\leq$ five years & $2.5(1.2)$ & $2.6(1.3)$ & $2.6(1.3)$ & $2.4(1.3)$ \\
\hline$>$ five and $\leq 10$ years & $2.2(1.3)$ & $2.2(1.3)$ & $2.6(1.3)$ & $2.3(1.3)$ \\
\hline Over 10 years & 2.2. (1.4) & $2.0(1.2)$ & $2.0(1.3)$ & $2.4(1.3)$ \\
\hline$p$-value ${ }^{* *}$ & 0.184 & 0.008 & $<0.001$ & 0.795 \\
\hline Satisfied & & & & \\
\hline \multicolumn{5}{|l|}{ Profession } \\
\hline Yes & $3.8(0.7)$ & $2.4(0.6)$ & $3.2(0.8)$ & $3.1(0.9)$ \\
\hline No & $3.8(0.7)$ & $2.6(0.6)$ & $3.4(0.7)$ & $3.1(0.9)$ \\
\hline$p$-value & 0.921 & 0.011 & 0.010 & 0.685 \\
\hline
\end{tabular}

\section{Discussion}

The characteristics of PHC workers in this study is consistent with those described in other studies [5,29-32]. The predominance of female professionals is due to the feminization process that health professions have undergone in many countries, including Brazil, in recent decades [33,34]. Moreover, the professional structure of the teams is consistent with that proposed by the National Primary Care Policy particularly with regards to the composition of the minimum number of FHS teams [1].

The coping strategy presented most among the PHC professionals in this study was problem-focused, which involves becoming aware of/identifying the stressor agent in order to manage or solve the problematic situation that causes them exhaustion/fatigue and stress. Through the process of reframing the problem, the professionals who adopt this strategy make cognitive efforts to perceive the problem in a positive way and, from there, attempt to face it $[16,35]$. These results corroborate the findings of other studies conducted with healthcare professionals that also presented the problem-focused strategy as the main coping strategy $[23,25,35,36]$.

For the professional to develop effective coping skills, it is necessary to be aware of the presence of the stressor agent, which will allow him to adopt assertive coping mechanisms and achieve a reduction of occupational stress as a consequence [17]. In this sense, it is noteworthy that the way of coping depends on behavioral and cognitive strategies used to control external and internal demands, which generate overload and compromise the physical and mental capacity of the individual. Therefore, the coping process will depend on the interaction of the individual with the environment, and may 
be influenced by personality and previous experiences that allowed development of cognitive, behavioral, emotional, and social resources to face stressful situations [37,38].

Highest scores for the strategies focused on religious practices/fantastical thinking were presented among community health agents, female workers, those with family income up to one minimum wage, with more than 10 years of professional experience, and who reported being dissatisfied with their profession and whose dissatisfaction with their profession was identified as an important motivational factor. A religious outlook in the work place encourages the worker's involvement with colleagues and favors the alignment of personal goals with organizational ones. Furthermore, spirituality is important for the construction of individual and community resilience, since it favors mutual support and enables groups (in this case, the FHS team) to share their needs, find strategies, and develop resources to face problems $[39,40]$.

The strategy based on the pursuit of social support, more evident among community health agents and female workers, shows the importance of expanding the network of social and emotional support to PHC workers. Thus, it is essential that managers encourage team meetings, which are important opportunities for listening to the demands of these professionals and sharing information that contributes to more effective confrontation of the problems present in the work practice, thereby reducing the risk of suffering and mental illness of these workers [25].

In the case of females, facing the problems can become even more difficult, since female workers' tasks are not over at the end of the work day, but can be but extend to domestic and child care. Therefore, female workers are more susceptible to overload and emotional stress, and require social support to face the workplace problems [41].

The results also revealed that younger workers, those with more than 10 years of PHC experience and those who are dissatisfied with their profession tend to adopt emotion-focused coping strategies, that is, they are more likely to develop denial and escape strategies, demonstrate feelings of tension and anger, and withdraw from problems and stressful situations. In this circumstance, it is common for workers to engage in behaviors that alleviate suffering such as alcohol consumption and use of illicit drugs [42-44].

Moreover, these professionals experience feelings of discouragement and hopelessness which compromise productivity and quality of life, and further, hinder the adoption of more positive and assertive responses to a stressful situation [45-49]. Therefore, because these workers show difficulty in facing their problems, they deserve special attention from managers and other professionals within the team.

Finally, it is noteworthy that workers with more than 10 years of professional experience tend not to adopt emotion-focused strategies and/or religious practices/fantastical thinking. This may be due to their extensive professional experience, which brings the maturity needed to react in a more assertive, concrete, and objective way when faced with stressful situations, without great emotional attachment and free of unpleasant feelings [50,51].

The cross-sectional design of this study does not make it possible to establish cause and effect relationships, or perform further analysis on coping strategies and sociodemographic and professional characteristics of PHC workers. However, the results should be carefully analyzed, since coping strategies are essential to solve problems and manage stressful situations that permeate the PHC work environment. Another limitation of the study is the inclusion of professionals from a single municipality, which does not allow the generalization of the results. However, this study distinguishes itself by allowing the understanding of coping strategies adopted by PHC workers and promoting the development of interventions that can strengthen the negative aspects and consolidate the positive aspects of this reality. 


\section{Conclusions}

The study showed that PHC professionals adopt different coping strategies for the problems and stressful situations experienced in the work environment. These strategies can involve more positive attitudes aimed at management and problem solving, to emotional responses that involve attitudes of avoidance and denial of the problem.

Considering that confronting problems in a positive manner is the best way to deal with the oppressive situations that arise in the work environment, it is essential that managers create support structures that encourage and strengthen the capacity of PHC professionals to adopt assertive strategies to face and solve problems.

Author Contributions: Conceptualization, L.G.L.; methodology, L.G.L.; software, L.G.L.; validation, L.G.L., B.M.R., N.S.G.M.S.S., M.J.C.P., F.R.G.X.N., F.A.B.M., M.L.S.G.S, J.G.M.P., D.M.G., B.M.P.S., I.C.K.O.C., J.F.O., M.S.A., C.L.F.C., F.G.S., N.P.F., V.F.N., S.T.R., T.M.C., M.L., J.L.C. and N.A.M.D.; formal analysis, L.G.L.; investigation, L.G.L. and B.M.R.; resources, L.G.L.; data curation, L.G.L.; writing - original draft preparation, L.G.L. and B.M.R.; writing - review and editing, N.S.G.M.S.S., M.J.C.P., F.R.G.X.N., F.A.B.M., M.L.S.G.S, J.G.M.P., D.M.G., B.M.P.S., I.C.K.O.C., J.F.O., M.S.A., C.L.F.C., F.G.S., N.P.F., V.F.N., S.T.R., T.M.C., M.L., J.L.C. and N.A.M.D.; visualization, L.G.L., B.M.R., N.S.G.M.S.S., M.J.C.P., F.R.G.X.N., F.A.B.M., M.L.S.G.S, J.G.M.P., D.M.G., B.M.P.S., I.C.K.O.C., J.F.O., M.S.A., C.L.F.C., F.G.S., N.P.F., V.F.N., S.T.R., T.M.C., M.L., J.L.C. and N.A.M.D.; supervision, L.G.L. and N.A.M.D.; project administration, L.G.L. All authors have read and agreed to the published version of the manuscript.

Funding: This research received no external funding.

Institutional Review Board Statement: The study was conducted according to the guidelines of the Declaration of Helsinki and was approved by the Research Ethics Committee at School of Medicine of São José do Rio Preto (decision: 1,776,737; CAAE: 59604116.0.0000.5415) on October 16, 2016.

Informed Consent Statement: Informed consent was obtained from all subjects involved in the study.

Data Availability Statement: The datasets generated during the current study are not publicly available but are available from the corresponding author on reasonable request.

Conflicts of Interest: The authors declare no conflict of interest. 


\section{References}

1. Ministério da Saúde (BR). Portaria n. 2.436, de 21 de setembro de 2917. Aprova a Política Nacional de Atenção Básica, estabelecendo a revisão de diretrizes para a organização da Atenção Básica, no âmbito do Sistema Único de Saúde (SUS). Brasília (DF): Ministério da Saúde, 2017. Available online: http://bvsms.saude.gov.br/bvs/saudelegis/gm/2017/prt2436 2209 2017.html (accessed on 16 Jan 2022).

2. Silva, L.A.; Casotti, C.A.; Chaves, S.C. A produção científica brasileira sobre a Estratégia Saúde da Família e a mudança no modelo de atenção. Ciênc. Saúde Colet. 2013, 18, $221-32$. http://dx.doi.org/10.1590/S1413-81232013000100023

3. Ferraz, F.C.; Francisco, F.R.; Oliveira, C.S. Estresse no ambiente de trabalho. Arch Health Invest 2014, 3, 1-8. Available online: http://archhealthinvestigation.com.br/ArcHI/article/view/797 (accessed on 16 Jan 2022).

4. Castro, J.R.; Gazetta, C.E.; Silva, A.G.; Sodré, P.C., Lourenção, L.G. Occupational stress and engagement in oral health professionals. Rev. bras. promoç. saúde 2019, 32, 9157. Recuperado em 02 de fevereiro de 2021, de http://dx.doi.org/10.5020/18061230.2019.9157

5. Cordioli, D.F.C.; Cordioli Junior, J.R.; Gazzeta, C.E.; Silva, A.G.; Lourenção, L.G. Occupational stress and work engagement in primary health care workers. Rev Bras Enferm 2019, 72, 1580-1587. http://dx.doi.org/10.1590/0034-7167-2018-0681

6. Santos, S.C.R.; Viegas, A.I.F.; Morgado, C.I.M.O.; Ramos, C.S.V.; Soares, C.N.D.; Roxo, H.M.C.J.; Santos, M.C.S.; Nabais, S.N.P. Prevalência de burnout em médicos residentes de Medicina Geral e Familiar em Portugal. Rev. bras. med. fam. comunidade 2017, 12, 1-9. https://doi.org/10.5712/rbmfc12(39)1430

7. Moreira, I.J.B.; Horta, J.A.; Duro, L.N.; Borges, D.T.; Cristofari, A.B.; Chaves, J.; Bassani, D.C.H.; Cerizolli, E.D.; Teixeira, R.M. Perfil sociodemográfico, ocupacional e avaliação das condições de saúde mental dos trabalhadores da Estratégia Saúde da Família em um município do Rio Grande do Sul, RS. Rev. bras. med. fam. comunidade 2016, 11, 1-12. https://doi.org/10.5712/rbmfc11(38)967

8. Carreiro, G.S.P.; Ferreira Filha, M.O.; Lazarte, R.; Silva, A.O.; Dias, M.D. O processo de adoecimento mental do trabalhador da Estratégia Saúde da Família. Rev. eletrônica enferm 2013, 15, $146-55$. http://dx.doi.org/10.5216/ree.v15i1.14084

9. Pinto, D.R.; Almeida, T.E.P.; Miyazaki, M.C.O.S. A saúde e estresse ocupacional em médicos. Arch. Health Sci. (Online) 2010, 17(4), 201-205. Available online: http://repositorio-racs.famerp.br/racs ol/vol-17-4/IDR\%207.pdf (accessed on 16 Jan 2022).

10. Suyama, E.H.T.; Lourenção, L.G.; Cordioli, D.F.C.; Cordioli Junior, J.R.; Miyazaki, M.C.O.S. Occupational stress and musculoskeletal symptoms in Community Health Workers. Cad. Bras. Ter. Ocup. 2022, 30 , e2992. https://doi.org/10.1590/2526-8910.ctoAO22692992

11. Neves, L.; Oliveira, M.L.M.C.; Ferreira, D.F.; Batista, E.C. Sintomatologia de estresse em policiais militares numa cidade do interior de Rondônia. Reinpec 2016, 2, 191-204. Available online: http://reinpec.srvroot.com:8686/reinpec/index.php/reinpec/article/view/163/60 (accessed on 16 Jan 2022).

12. Santos, F.B.; Lourenção, L.G.; Veira, E.; Ximenes Neto, F.R.G.; Oliveira, A.M.N.; Oliveira, J.F. Occupational stress and work engagement among Military Police Officers. Ciênc. saúde coletiva 2021, 26, 5987-5996. https://doi.org/10.1590/1413-812320212612.14782021

13. Silva, S.C.P.S.; Nunes, M.A.P.; Santana, V.R.; Reis, F.P.; Machado Neto, J.; Lima, S.O. A síndrome de burnout em profissionais da Rede de Atenção Primária à Saúde de Aracaju, Brasil. Ciênc. saúde coletiva 2015, 20, $3011-3020$. http://dx.doi.org/10.1590/1413-812320152010.19912014.19 
14. Melo, L.P.; Carlotto, M.S.; Rodriguez, S.Y.S.; Diehl, L. Estratégias de enfrentamento (coping) em trabalhadores: revisão sistemática da literatura nacional. Arq. bras. psicol. 2016, 68, 125-144. Available online: http://pepsic.bvsalud.org/scielo.php?script=sci arttext\&pid=S1809-52672016000300010 (accessed on 16 Jan 2022 ).

15. Pinheiro, F.A.; Tróccoli, B.T.; Tamayo, M.R. Mensuração de coping no ambiente ocupacional. Psicol. teor. pesqui. 2003, 19, 153-158. https://dx.doi.org/10.1590/S0102-37722003000200007

16. Seidl, E.M.F.; Tróccoli, B.T.; Zannon, C.M.L.C. Análise fatorial de uma medida de estratégias de enfrentamento. Psic.: Teor. e Pesq. 2001, 17, 225-234. http://dx.doi.org/10.1590/S0102-37722001000300004

17. Gómez-Gascón, T.; Martín-Fernández, J.; Gálvez-Herrer, M.; Tapias-Merino, e.; Beamud-Lagos, M.; Mingote-Adán, J.C.; Edesproap-Madrid G. Effectiveness of an intervention for prevention and treatment of burnout in primary health care professionals. BMC Fam Pract 2013, 14, 173. https://doi.org/10.1186/1471-2296-14-173

18. Lichner, V.; Halachová, M.; Lovaš, L. The concept of self-care, work engagement, and burnout syndrome among Slovak social worker. Czech and Slovak Social Work 2018, 4, 62-75. Available online: https://socialniprace.cz/article/the-concept-of-self-care-work-engagement-and-burnout-syndrome-among-slovaksocial-workers/ (accessed on 16 Jan 2022).

19. Monteiro, J.; Grisa, G.; Sobrosa, G.; Rodrigues, M. Fatores Associados à Síndrome de Burnout em Profissionais que Tratam da Saúde da Mulher. Rev. psicol. IMED 2016, 8, 3-13. https://doi.org/10.18256/2175-5027/psico-imed.v8n1p3-13

20. Rodrigues, D.P.; Athanázio, A.R.; Cortez, E.A.; Teixeira, E. R.; Alves, V.H. Stress in the intensive care unit: integrative review. J Nurs UFPE on line 2013, 7, 1595-1604. Available online: https://periodicos.ufpe.br/revistas/revistaenfermagem/article/download/11651/34524 (accessed on 16 Jan 2022 ).

21. Vieira, N.; Nogueira, D.; Terra, F. Stress assement among hospital nurses. Rev. enferm. UERJ 2017, 25, e14053. http://dx.doi.org/10.12957/reuerj.2017.14053

22. Silva, D.P.; Silva, M.N.R.M.O. O trabalhador com estresse e intervenções para o cuidado em saúde. Trab. educ. saúde 2015, 13, 201-214. https://doi.org/10.1590/1981-7746-sip00032

23. Ribeiro, R.M.; Pompeo, D.A.; Pinto, M.H.; Ribeiro, R.C.H.M. Estratégias de enfrentamento dos enfermeiros em serviço hospitalar de emergência. Acta paul. enferm 2015, 28, 216-223. https://doi.org/10.1590/1982-0194201500037

24. Maturana, A.P.P.M.; Valle, T.G.M. Estratégias de enfrentamento e situações estressoras de profissionais no ambiente hospitalar. Psicol. hosp. (São Paulo) 2014, 12, 02-23. Available online: http://pepsic.bvsalud.org/scielo.php?script=sci arttext\&pid=S1677-74092014000200002\&lng=pt\&tlng=pt (accessed on 16 Jan 2022).

25. Faria, FR.C.; Lourenção, L.G.; Silva, A.G.; Sodré, P.C.; Castro, J.R.; Borges, M.A.; Gazetta, C.E. Occupational stress, work engagement and coping strategies in Community Health Workers. Rev. Rene 2021, 22, e70815. http://dx.doi.org/10.15253/2175-6783.20212270815

26. Marques, A.C.C.; Barroso, S.M. Coping strategies of psychologists in a non-governmental CAPS. Rev. Fam., Ciclos Vida Saúde Contexto Soc 2019, 7, 458-469. https://doi.org/10.18554/refacs.v7i4.3639

27. Instituto Brasileiro de Geografia e Estatística. População de São José do Rio Preto. 2017. Available online: https://cidades.ibge.gov.br/brasil/sp/sao-jose-do-rio-preto/panorama (accessed on 16 Jan 2022).

28. Prefeitura de São José do Rio Preto (BR). Painel de Monitoramento 2018 - Indicadores de 2017. Available online: http://saude.riopreto.sp.gov.br/transparencia/arqu/painmoni/painel-monitoramento-2018.pdf (accessed on 16 Jan 2022). 
29. Cordioli Junior, J.R.; Cordioli, D.F.C.; Gazetta, C.E.; Silva, A.G.; Lourenção, L.G. Quality of life and osteomuscular symptoms in workers of primary health care. Rev. bras. enferm 2020, 73, e20190054. https://dx.doi.org/10.1590/0034-7167-2019-0054

30. Lourenção, L.G.; Silva, A.G.; Borges, M.A. Levels of engagement in primary health care professionals: a comparative study in two Brazilian municipalities. Esc Anna Nery 2019, 23, e20190005. https://doi.org/10.1590/2177-9465-ean-2019-0005

31. Maissiat, G.S.; Lautert, L.; Pai, D.D.; Tavares, J.P. Work context, job satisfaction and suffering in primary health care. Rev. gaúch. enferm 2015, 36(2):42-9. http://dx.doi.org/10.1590/1983-1447.2015.02.51128

32. Medeiros, P.A.; Silva, L.C.; Amarante, I.M.; Cardoso, V.G.; Mensch, K.M.; Naman, M.; Schimith, M.D. Condições de saúde entre profissionais da atenção básica em saúde do município de Santa Maria - RS. Rev. Bras. Ciênc. Saúde (João Pessoa, Online) 2016, 20, 115-22. http://dx.doi.org/10.4034/RBCS.2016.20.02.04

33. Matos, I.B.; Toassi, R.F.C.; Oliveira, M.C. Profissões e ocupações de saúde e o processo de feminilização: tendências e implicações. Athenea Digital 2013, 13, 239-44. https://doi.org/10.5565/rev/athenead/v13n2.1119

34. Wermelinger, M.; Machado, M.H.; Lobato, M.F.; Oliveira, E.S.; Moysés, N.N.; Ferraz, W. A feminilização do mercado de trabalho em saúde no Brasil. Divulg. saúde debate 2010, 45, 54-70. Available online: http://capacidadeshumanas.org/trajetoriainstitucionaldosus/wp-content/uploads/2017/11/Afeminilizacaodomer cadodetrabalho Wermelinger.pdf (accessed on 16 Jan 2022).

35. Pereira, S.S.; Teixeira, C.A.B.; Reisdorfer, E.; Vieira, M.V.; Gherardi-Donato, E.C.S.; Cardoso, L. The Relationship Between Occupational Stressors And Coping Strategies In Nursing Technicians. Texto E contexto enferm 2016, 25(4), e2920014. Recuperado em 10 de dezembro de 2021, de https://doi.org/10.1590/0104-07072016002920014.

36. Teixeira, C.A.B.; Gherardi-Donato, E.C.S.; Pereira, S.S.; Cardoso, L.; Reisdorfer, E. Estresse ocupacional e estratégias de enfrentamento entre profissionais de enfermagem em ambiente hospitalar. Enferm. glob 2016, 44, 299-309. Available online: https://revistas.um.es/eglobal/article/view/228761/198191 (accessed on 16 Jan 2022).

37. Pereira, T.B.; Rodrigues, V.L.B. As estratégias de coping na promoção à saúde mental de pacientes oncológicos: uma revisão bibliográfica. Rev. Psicol. Saúde 2016, 8, 24-31. http://dx.doi.org/10.20435/2177093X2016104

38. Mussumeci, A.M.; Ponciano, T.E.L. Estresse, coping e experiências emocionais: uma análise das respostas de enfrentamento do casal. Pensando famílias 2017, 21, 33-49. Available online: http://pepsic.bvsalud.org/scielo.php?script=sci arttext\&pid=S1679-494X2017000100004\&lng=pt\&tlng=pt (accessed on 16 Jan 2022).

39. Cafezeiro, A.S.; Cunha, A.L.G.O.; De La Longuiniere, A.C.; Silva, M.C.Q.S.; Santos, A.L.B.; Yarid, S.D. A espiritualidade no enfrentamento de crises globais. Rev. Pró-UniverSUS 2020, 11, 168-173. https://doi.org/10.21727/rpu.v11i2.2367

40. Sholikhah, Z.; Wang, X.; Li, W. The role of spiritual leadership in fostering discretionary behaviors: the mediating effect of organization based self-esteem and workplace spirituality. Int. J. Law Manag 2019, 61, $232-249$. https://doi.org/10.1108/ijlma-04-2018-0081

41. Vargas, I.C. Efeitos do cruzamento de gênero, raça e classe na vida de trabalhadoras de um empreendimento de reciclagem: uma leitura através da interseccionalidade. Master's Thesis, Vale do Rio dos Sinos University, Porto Alegre, RS, Brazil, 2019. Available online: http://www.repositorio.jesuita.org.br/handle/UNISINOS/8804 (accessed on 16 Jan 2022).

42. Dehelean, L.; Papava, I.; Musat, M.I.; Bondrescu, M.; Bratosin, F.; Bucatos, B.O.; Bortun, A.C.; Mager, D.V.; Romosan, R.S.; Romosan, A.M.; Paczeyka, R.; Cut, T.G.; Pescariu, S.A.; Laza, R. Coping Strategies and Stress 
Related Disorders in Patients with COVID-19. Brain sciences 2021, 11, 1287. https://doi.org/10.3390/brainsci11101287

43. Sousa, P.S.A.; Faria, M.D.; Souza, D.M.O.R. Enfrentamento de familiares de crianças e adolescentes com câncer: uma abordagem quantitativa. Rev. Enferm. Digit. Cuid. Promoção Saúde 2021, 6, 1-8. https://doi.org/10.5935/2446-5682.20210054

44. Stanisławski K. The Coping Circumplex Model: An Integrative Model of the Structure of Coping With Stress. Front. Psychol 2019, 10, 694. https://doi.org/10.3389/fpsyg.2019.00694

45. Michalak, R.T.; Kiffin-Petersen, S.A.; Ashkanasy, N.M. I Feel Mad So I Be Bad: The Role of Affect, Dissatisfaction and Stress in Determining Responses to Interpersonal Deviance. Br. J. Manag 2019, 30, 645-667. https://doi.org/10.1111/1467-8551.12286

46. Wallace, J.E. Burnout, coping and suicidal ideation: An application and extension of the job demand-control-support model. J. Workplace Behav. Health 2017, 32, 99-118. https://doi.org/10.1080/15555240.2017.1329628

47. Lourenção, L.G.; Back, C.R.; Santos, C.B.; Sousa, C.P. Qualidade de vida de agentes comunitários de saúde de um município do interior do Estado de São Paulo. Arch. Health Sci. (Online) 2012, 19, 19-27. Available online: https://repositorio-racs.famerp.br/racs ol/vol-19-1/IDW\%203\%20-\%20JAN\%20-\%20MAR\%202012.pdf (accessed on 16 Jan 2022).

48. Lourenção, L.G.; Ximenes Neto, F.R.G.; Silva, A.G.; Borges, M.A.; Gazetta, C.E. Análise do engajamento no trabalho em agentes comunitários de saúde no período pré-pandêmico. J. Health NPEPS 2021, 6, 90-103. http://dx.doi.org/10.30681/252610106012

49. Julio, R.S.; Lourenção, L.G.; Oliveira, S.M.; Farias, D.H.R.; Gazetta, C.E. Prevalence of anxiety and depression in Brazilian Primary Health Care workers. Cad. Bras. Ter. Ocup. 2022, 30, e2997. https://doi.org/10.1590/2526-8910.ctoAO22712997

50. Asnis, T.G. Relações entre resiliência, trauma e envelhecimento. Master's Thesis, Pontifícia Universidade Católica do Rio Grande do Sul (PUCRS), Porto Alegre, RS, Brazil, 2021. Available from: https://repositorio.pucrs.br/dspace/bitstream/10923/18039/1/000500552-Texto\%2Bcompleto-0.pdf (accessed on 16 Jan 2022).

51. Blix, S.B.; Wettergren, A. Professional Emotions in Court: A Sociological Perspective, 1st ed.; Routledge: England, UK, 2018. https://doi.org/10.4324/9781315306759 